СУТНІСТЬ КОГНІТИВНОГО КОМПОНЕНТА ПАТРІОТИЧНОЇ РЕФЛЕКСІЇ ОСОБИСТОСТІ

\section{THE ESSENCE OF THE COGNITIVE COMPONENT OF PATRIOTIC REFLECTION OF PERSONALITY}

УДК 159.923:37.035.6

DOI https://doi.org/10.32843/2663-

5208.2020.12-2.30

Михальченко Н.В.

к.психол.н., доцент кафедри педагогіки та інклюзивної освіти

Миколаївський національний

університет імені В.О. Сухомлинського
У статті визначено динаміку розвитку когнітивного складника патріотичної рефрлексії особистості пізньої юності в умовах здобуття вищої освіти. Молоде покоління потребує не тільки системи наукових знань, а перш за все цілісної національної культури, духовності, патріотичного покликання. Орієнтація на ту чи іншу систему цінностей визначає характер розвитку особистості, цілеспрямоване формування ціннісного ставлення до дійсності - одне з найважливіших місць у системі патріотичного виховання та формування патріотичної ресрлексії. У процесі психічного розвитку особистості виникає фрормування рефрлексивних складників індивіда, що формується ідеєю його «Я»,, ототожнюється як емоційно-пізнавальний процес ідентиярікації суб'єкта з іншим суб'єктом, групою людей. Для вивчення динаміки рівня розвитку пізнавального складника патріотичної рефрлексії особистості пізнього юнацького віку ми провели констатувальний експеримент першого порядку. Психодіагностика розвитку когнітивного складника патріотичної ресрлексії особистості пізньої юності проводилася за допомогою методу анкетування та проєктивного методу. Серед основних якісних показників низького рівня розвитку пізнавального складника патріотичної ресрлексії ми визначаємо: відсутність почуття індивідуальної відповідальності та почуття патріотичної гідності; відсутність віри в свої сили, готовність внести конкретний особистий внесок у розвиток певної сфрери життя, культури, відродження та розвитку української держави. За результатами констатувального експерименту першого порядку визначено, що рівень розвитку когнітивного складника від першого року навчання студентів до навчання у магістратурі значно підвищується за рахунок упровадження у закладі інноваційних форм роботи та авторських програм. Критеріями оцінки рівня розвитку когнітивного складника стали: рівень самоаналізу власних знань про історію держави, рід, народ.

Ключові слова: рефрлексія, патріотична ресрлексія, самосвідомість, чінності, ціннісні оріентації.

The work determines the dynamics of the development of the cognitive com- ponent of the patriotic reflection of the personality in the context of higher education. The younger generation needs to acquire not only a system of scientific knowledge, but above all a holistic national culture, spirituality, patriotic vocation. Orientation to one or another system of values determines the nature of personality development, the purposeful formation of a value relation to reality is one of the most important places in the system of patriotic education and the formation of patriotic reflection. In the process of mental development of the individual there is the formation of reflexive components of the individual, formed the idea of his "I", identifies as an emotional and cognitive process of identifying the subject with another subject, a group of people. In order to study the dynamics of the level of development of the cognitive component of the patriotic reflection of the personality of late adolescence, we conducted a first-order verification experiment. Psychodiagnostics of the development of the cognitive component of the patriotic reflection of the personality of late adolescence was carried out using the questionnaire method and the projective method. Among the main qualitative indicators of the low level of development of the cognitive component of patriotic reflection, we determine the following: there is no sense of individual responsibility and a sense of patriotic dignity; lack of faith in their strength, readiness to make a concrete personal contribution to the development of a certain sphere of life, culture, the revival and development of the Ukrainian state. According to the results of the first-order confirmatory experiment, it is determined that the level of development of the cognitive component, from the first year of studying students to studying in the magistracy, is significantly increased due to the introduction of innovative forms of work and author's programs in the institution. Criteria for assessing the level of development of the cognitive component of steel: the level of self-examination of own knowledge about the history of the state, race, people.

Key words: reflection, patriotic reflection, consciousness, values, value orientations.
Вступ. Демократична розбудова української держави ставить на порядок денний надзвичайно важливе й невідкладне завдання виховання справжнього громадянина і патріота рідної землі. Для відродження української нації та розвитку її духовності, патріотизму необхідні зміни у змісті та спрямуванні виховних технологій, акцентування на розвитку патріотичної самосвідомості особистості. Кризові явища, що проявились у перехідний період в українському суспільстві, зумовлені значною мірою кризою патріотичної свідомості його громадян, вимагають відновлення української ментальності, формування моральних цінностей та ідеалів. Наш час вимагає відродження і розвитку української національної системи освіти і виховання. Сучасна психологічна наука безперервно повинна еволюціонувати, набу- 
вати дедалі глибшого патріотичного змісту і характеру.

Нині виникла нагальна необхідність створення сприятливих умов для оволодіння молодою особистістю досвідом здійснення самоперетворювальних змін, саморозвитку патріотизму, що можливе, на нашу думку, на основі рефлексії особистості.

Виклад основного матеріалу дослідження. Одностайно надаючи вихованню любові до Батьківщини пріоритетного значення, вітчизняні педагоги Г.В. Ващенко, О.І. Вишневський, С.Ф. Русова, М.Г. Стельмахович, В.О. Сухомлинський вбачають джерела патріотизму в любові до рідної сім'ї, природи, мови, культури, навчального закладу, міста (села) тощо. Розвиток патріотичної рефлексії особистості пов'язано з осмисленням наукового доробку, який внесли в дослідження загальнотеоретичних і методологічних проблем психології Б.Г. Ананьєв, Р. Бернс, Л.І. Божович, А. Валлон, Д.Б. Ельконін, І.С. Кон, О.М. Леонтьєв, С.Д. Максименко, К. Роджерс, а також з дослідженням проблем національної ідентифікації, духовності особистості у психологічній, філософсько-етичній літературі, які провели М.О. Бердяєв, І.Д. Бех, М.Й. Боришевський, М.С. Грушевський, Ю.Д. Руденко, А. Шопенгауер, В.О. Сухомлинський, К.Д. Ушинський.

В окремих дослідженнях розглядаються деякі питання зазначеної проблеми, зокрема, поняття «національна рефлексія» (М.А. Шугай), виховання патріотичних почуттів у студентської молоді (В.Д. Будак), поняття комунікативних практик та стратегії соціальної взаємодії в контексті громадянської та національної самоідентифікації студентської молоді (С.І. Позняк), виховання національно-патріотичних почуттів у дошкільників засобами національної символіки (К.В. Мазур), моральної саморегуляції (О.С. Безверхий), рефлексії підлітків (О.В. Савицька), рефлексії процесу навчання (Л.М. Співак), патріотичної рефлексії молодших школярів (Н.В. Михальченко).

Мета статті - визначити сутність рівнів розвитку когнітивного складника патріотичної рефлексії особистості пізньої юності в умовах здобуття вищої освіти.

Психологічний стан сучасного українського суспільства, який детермінований складними процесами соціально-економічного реформування, потребує особливої уваги до патріотичного виховання молодого покоління. У процесі навчання, виховання і розвитку молоді треба брати до уваги, що всі сфери життєдіяльності будь-якої цивілізованої нації пройняті і зцементовані ідеями, принципами, ідеалами, які мають, з одного боку, високу самобутність, з іншого втілюють у собі загальнолюдський зміст.
Молодому поколінню потрібно оволодіти не лише системою наукових знань, а насамперед цілісною національною культурою, духовністю, патріотичним покликанням. Висока ефективність навчально-виховного процесу значною мірою залежить від тих ідейних засад, на яких ґрунтується зміст освіти, здійснюється формування молодих поколінь.

Велику увагу для визначення феномена патріотичної рефлексії треба приділити ціннісним орієнтаціям особистості. У психологічному аспекті проблему становлення ціннісної сфери особистості розробляли Л.Е. Орбан-Лембрик [8], І.С. Булах [3], К.О. Островська [7], П.В. Лушин [4].

Як зазначила Л.Е. Орбан-Лембрик, ціннісно-смислова сфера - складне цілісне утворення, представлене передусім ціннісними орієнтаціями, які формуються у разі засвоєння соціального досвіду, виявляються у меті, ідеалах, переконаннях, інтересах, $€$ важливим чинником соціальної регуляції взаємин людей і поведінки індивіда [8, с. 84]. Ціннісні орієнтації - це важливі елементи структури особистості. Вони реалізуються у спрямованості інтересів і потреб особистості на певну ієрархію життєвих цінностей, у схильності надавати перевагу одним цінностям і заперечувати інші. Треба відзначити, що у спілкуванні та взаємодії ціннісні орієнтації тісно пов'язані з пізнавальними та вольовими особливостями комунікативного процесу і утворюють змістовий аспект спрямованості особистості і виражають її готовність, внутрішню основу ставлення до дійсності.

Оскільки орієнтація на ту чи іншу систему цінностей зумовлює характер розвитку особистості, цілеспрямоване формування ціннісного ставлення до дійсності посідає одне з найважливіших місць у системі патріотичного виховання та формування патріотичної рефлексії. Однією із суттєвих ознак психічного розвитку особистості є подальше становлення самосвідомості, яке виявляється у диференціації її внутрішньої структури, ускладненні змістового наповнення та зміни функціональної ролі у процесах регуляції та саморегуляції. У зрілому юнацькому віці, на думку М.В. Савчина, становлення самосвідомості зумовлюється внутрішніми суперечностями особистості [9, с. 261].

у структурі самосвідомості особистості формуються три провідні компоненти: образ «Я», самооцінка та ціннісні орієнтації. Наступні три компоненти забезпечують рівень сформованості самосвідомості, яка своєю чергою $€$ основою для формування та розвитку рефлексії.

І.Д. Бех у своїх наукових дослідженнях дійшов висновку, що «патріотизм - це особливе, тобто безумовне і високосмислове почут- 
тя-цінність, яке характеризує ставлення особистості до народу, Батьківщини, держави та до самої себе» [1, с. 151].

Патріотична рефлексія - це самоусвідомлення (самооцінка, самопізнання, саморозуміння, самовідчуття) людиною душевного стану, своїх вчинків, самоаналіз та сприйняття спільних психологічних особливостей менталітету, осмислення свого минулого, нинішнього і майбутнього та приналежності до своєї нації, до свого народу [6, с. 151].

На основі аналізу сутності поняття «патріотична рефлексія» нами була розроблена структурна модель патріотичної рефлексії особистості [6, с. 153]. Модель являє собою складний процес самооцінки рівнів розвитку таких компонентів патріотичної самосвідомості, як когнітивного, емоційного, поведінкового.

У Миколаївському національному університеті імені В.О. Сухомлинського вже третій рік поспіль на факультеті дошкільної та початкової освіти серед магістрів другого року навчання впроваджується авторська програма «Національно-патріотичне виховання в закладах освіти» [2]. Курс «Національно-патріотичне виховання в закладах освіти» є однією з вибіркових навчальних дисциплін, яка належить до циклу вільного вибору студентів. Інтеграційні процеси, що відбуваються в Україні, європоцентричність, пробудження громадянської і громадської ініціативи, виникнення різних громадських рухів, поширення волонтерської діяльності, які накладаються на технологічну і комунікативну глобалізацію, міграційні зміни всередині суспільства, ідентифікаційні і реідентифікаційні процеси в особистісному розвитку кожного українця, відбуваються на тлі сплеску інтересу і прояву патріотичних почуттів і нових ставлень до історії, культури, релігії, традицій і звичаїв українського народу [10, с. 266]. Тому нині, як ніколи, потрібні нові підходи і нові шляхи до виховання патріотизму як почуття і як базової якості особистості.

Зокрема, нами вже було проведено дослідження самооцінки студентами чинників, які негативно впливають на розвиток патріотичної рефлексії особистості в сім'ї [5, с. 59]. Крім того, нами були визначені критерії оцінки рівня розвитку патріотичної рефлексії особистості та якісні показники рівнів розвитку патріотичної рефлексії особистості пізньої юності. Серед критеріїв визначені такі як: рівень самоаналізу власних знань про історію держави, рід, народ (когнітивний складник патріотичної рефлексії); емоційне реагування на суспільні справи, власну участь у патріотичних вчинках (емоційний складник патріотичної рефлексії); самооцінка своїх соціально значущих вчинків, власної поведінки (поведінковий складник патріотичної рефлексії.

3 метою вивчення динаміки рівня розвитку когнітивного складника патріотичної рефлексії особистості пізньої юності нами було проведено констатувальний експеримент першого порядку на базі Миколаївського національного університету імені В.О. Сухомлинського. Констатувальний експеримент був спрямований на вивчення динаміки розвитку когнітивного складника патріотичної рефлексії особистості в умовах здобуття вищої освіти. Обробка результатів дослідження включала якісний та кількісний аналіз виявлених особливостей, визначення достовірних відмінностей у прояві психологічних характеристик особистості, які мають значення для вибору подальшої психолого-педагогічної роботи щодо розвитку патріотичної рефлексії особистості. Психодіагностика розвитку когнітивного складника патріотичної рефлексії особистості пізньої юності була проведена за допомогою методу анкетування та проєктивного методу.

У психодіагностиці взяли участь групи студентів денної форми навчання факультету дошкільної та початкової освіти МНУ імені В.О. Сухомлинського загальною кількістю 219 осіб. Серед них - студенти першого курсу денної форми навчання (віком 17-18 років) 40 осіб, студенти другого курсу денної форми навчання (віком 18-19 років) - 46 осіб, студенти третього курсу денної форми навчання (віком 19-20 років) - 42 особи, студенти четвертого курсу денної форми навчання (віком 20-21 рік) - 45 осіб та студенти першого й другого років навчання магістратури (віком 21-23 роки) - 46 осіб. Студенти, які брали участь у дослідженні, відзначались неоднорідністю за успішністю, поведінковими реакціями, швидкістю виконання поставлених завдань.

На етапі констатувального експерименту першого порядку ми звернули увагу на рівень розвитку когнітивного складника патріотичної рефлексії особистості студента, готовності у майбутньому до національно-патріотичного виховання дітей дошкільного віку та молодшого шкільного віку, спроможності формувати патріотичну самосвідомость та етнічну ідентифікацію у молодого покоління.

Метод анкетування був спрямований на вивчення когнітивних умінь студента ідентифікувати себе зі своєю етнічною групою. Серед запитань анкети були запропоновані такі: «Як ви розумієте вислів «Я як представник певної нації»?», «Які весняні календарні свята вам найбільше подобаються і чому?», «Як ви відзначаєте свята у вашій родині? Які з них є традиційними?» та інші. Проєктивний метод був представлений методикою «Незакінчені речення». Метод був спрямований на вивчення ставлень студентів до себе, до своїх батьків, до свого народу, до інших людей. Серед незакінчених речень були запропоновані такі: «Я піклуюсь про батьків, тому що...», «Про мене піклуються батьки, тому що...», 
«Я люблю рідну землю, тому що...», «Я покладаю надію на Батьківщину, тому що...», «Я впевнений у майбутньому, тому що...» та інші.

Висновки 3 проведеного дослідження. Результати дослідження за методом анкетування та проєктивним методом представлені в таблиці 1.

Як видно з таблиці 1, серед студентів першого курсу віком 17-18 років переважає середній рівень розвитку когнітивного складника патріотичної рефлексії особистості пізньої юності (52,50\%), серед студентів другого курсу віком 18-19 років переважає також середній рівень розвитку когнітивного складника патріотичної рефлексії особистості пізньої юності (54,35\%), серед студентів третього курсу віком 19-20 років переважає також середній рівень розвитку когнітивного складника патріотичної рефлексії особистості пізньої юності (53,38\%), серед студентів четвертого курсу віком 20-21 рік переважає високий рівень розвитку когнітивного складника патріотичної рефлексії особистості пізньої юності $(46,67 \%)$, серед студентів першого та другого років навчання в магістратурі віком 21-23 роки переважає високий рівень розвитку когнітивного складника патріотичної рефлексії особистості пізньої юності $(58,70 \%)$.

Загалом, серед досліджуваних студентів склали більшу частку студенти із середнім рівнем розвитку когнітивного складника патріотичної рефлексії $(47,03 \%)$. Але занепокоєння викликають показники низького рівня розвитку когнітивного складника патріотичної рефлексії особистості (13,70\%).

Визначаємо, що за результатами констатувального експерименту першого порядку в онтогенетичній розгортці в умовах здобуття вищої освіти відбувається зростання високого рівня розвитку когнітивного складника патріо- тичної рефлексії від першого курсу $(25,00 \%)$ до навчання у магістратурі $(58,70 \%)$ та зменшення показника низького рівня від 22,50\% до 6,52\%.

Проведений аналіз дає можливість стверджувати, що робота 3 національно-патріотичного виховання молоді у закладах вищої освіти має бути продовжена та вдосконалена у напрямі формування саме патріотичної рефлексії у майбутніх вихователів та вчителів.

Результати дослідження 3 вивчення в динаміці рівнів розвитку когнітивного складника патріотичної рефлексії особистості пізньої юності дали змогу зробити такі висновки.

Серед студентів першого курсу віком 17-18 років переважає середній рівень розвитку когнітивного складника патріотичної рефлексії особистості пізньої юності (54,35\%), високий рівень - у 30,44\% респондентів, низький - у 15,21\% респондентів.

Серед студентів другого курсу віком 18-19 років переважає середній рівень розвитку когнітивного складника патріотичної рефлексії особистості пізньої юності (54,35\%), високий рівень - 30,44\% серед досліджуваних, низький рівень - 15,21\%.

Серед студентів третього курсу віком 19-20 років переважає середній рівень розвитку когнітивного складника патріотичної рефлексії особистості пізньої юності (52,38\%), високий рівень - у 33,34\% респондентів, низький - у $14,28 \%$ респондентів.

Серед студентів четвертого курсу віком 20-21 рік переважає високий рівень розвитку когнітивного складника патріотичної рефлексії особистості пізньої юності (46,67\%), середній рівень - у 42,22\% респондентів, низький у $11,11 \%$ респондентів.

Серед студентів першого та другого років навчання в магістратурі віком 21-23 роки переважає високий рівень розвитку когнітив-

Рівні розвитку когнітивного складника патріотичної рефлексії особистості пізньої юності на етапі констатувального експерименту першого порядку

\begin{tabular}{|c|c|c|c|c|c|c|}
\hline \multirow{3}{*}{ Категорія студентів } & \multicolumn{6}{|c|}{$\begin{array}{c}\text { Рівні розвитку когнітивного складника патріотич- } \\
\text { ної рефлексії особистості пізньої юності }\end{array}$} \\
\hline & \multicolumn{2}{|c|}{ Високий } & \multicolumn{2}{|c|}{ Середній } & \multicolumn{2}{|c|}{ Низький } \\
\hline & кількість & $\%$ & кількість & $\%$ & кількість & $\%$ \\
\hline $\begin{array}{l}\text { Студенти перших курсів віком 17-18 років } \\
\text { (N1=40) }\end{array}$ & 10 & 25,00 & 21 & 52,50 & 9 & 22,50 \\
\hline $\begin{array}{c}\text { Студенти других курсів віком 18-19 років } \\
\text { (N2=46) }\end{array}$ & 14 & 30,44 & 25 & 54,35 & 7 & 15,21 \\
\hline $\begin{array}{c}\text { Студенти третіх курсів віком 19-20 років } \\
\text { (N3=42) }\end{array}$ & 14 & 33,34 & 22 & 52,38 & 6 & 14,28 \\
\hline $\begin{array}{c}\text { Студенти четвертих курсів віком 20-21 рік } \\
(\mathrm{N} 4=45)\end{array}$ & 21 & 46,67 & 19 & 42,22 & 5 & 11,11 \\
\hline $\begin{array}{c}\text { Студенти першого та другого курсів } \\
\text { магістратури віком 21-23 роки (N5=46) }\end{array}$ & 27 & 58,70 & 16 & 34,78 & 3 & 6,52 \\
\hline $\begin{array}{c}\text { Загалом, студенти віком 17-23 роки } \\
(\mathrm{N}=219)\end{array}$ & 86 & 39,27 & 103 & 47,03 & 30 & 13,70 \\
\hline
\end{tabular}


ного складника патріотичної рефлексії особистості пізньої юності (58,70\%), середній рівень - у $34,78 \%$ респондентів, низький у $6,52 \%$ респондентів.

Загалом, серед досліджуваних студентів більшу частку становили студенти із середнім рівнем розвитку когнітивного складника патріотичної рефлексії $(47,03 \%)$. Студентів з високим рівнем розвитку - 39,27\%, з низьким рівнем $-13,70 \%$.

Серед основних якісних показників низького рівня розвитку когнітивного складника патріотичної рефлексії визначаємо такі: відсутні почуття індивідуальної відповідальності та почуття патріотичної гідності; відсутня віра у свої сили, готовність зробити конкретний особистий внесок у розвиток певної сфери життя, галузі науки, культури, у відродження і розбудову Української держави; відсутні знання про етнокультурні та етнопсихологічні особливості свого народу; не сформовані етнопсихологічні потреби, мотиви та інтереси, що виражається в активному прагненні до розвитку кращих рис українського характеру, національних інтересів, духовних цінностей, почуття патріотичної гідності.

у подальшому наше дослідження буде спрямоване на вивчення рівнів розвитку емоційного та поведінкового складників патріотичної рефлексії особистості пізньої юності в умовах здобуття вищої освіти.

\section{ЛІТЕРАТУРA:}

1. Бех І.Д. Вибрані наукові праці. Виховання особистості. Чернівці : Букрек, 2015. Т.1. 640 с.

2. Будак В.Д., Михальченко Н.В. Національнопатріотичне виховання в закладах освіти. Робоча програма навчальної дисципліни. / Автори-упорядники Будак В.Д., Михальченко Н.В. Миколаїв : МНУ імені В.О. Сухомлинського, 2017. 22 с.

3. Булах І.С., Кулагіна Л.М. Особливості соціального вибору ціннісних орієнтацій у підлітків. Ціннісні орієнтації в громадянському становленні особистості : науково-методичний збірник. Дрогобич : Відродження, 1998. С. 46-51.

4. Лушин П.В. Психология личностного изменения. Кировоград : ООО Имекс ЛТД, 2002. 360 с.

5. Михальченко Н.В. Детермінанти розвитку патріотичної ресрлексії особистості. Науковий вісник ХДУ. Серія «Психологічні науки» : зб. наук. праць ХДУ / За ред. О.Є. Блинової. Херсон : ВД «Гельветика», 2017. Вип. 6. Т.ІІ. С. 54-59.

6. Михальченко Н.В. Патріотична ресрлексія як новоутворення молодшого шкільного віку. Науковий вісник Миколаївського національного університету імені В.О. Сухомлинського : збірник наукових праць. Серія «Психологічні наукц». / за наук. ред. С.Д. Максименка, Н.О. Євдокимової. Миколаїв : МНУ ім. В.О. Сухомлинського, 2014. № 2.13 (109). C. 151-156.

7. Островська К.О. Взаємозалежність самооцінки та ціннісних орієнтацій молодших школярів. Соціальні технології. Актуальні проблеми теорії та практики. Київ; Запоріжжя; Одеса, 2002. Вип. 15. С. 117-123.

8. Орбан-Лембрик Л.Е. Соціальна психологія : посібник. Київ : Академвидав, 2003. 448 с.

9. Савчин М.В. Вікова психологія : навчальний посібник / М.В. Савчин, Л.П. Василенко. Київ : Академвидав, 2005. 360 c.

10. Mykhalchenko N.V. The role of Ukrainian symbol and folklore in the development of patriotic reflection of personality. Imperatives of given society development in promoting national competitiveness. Volume II, December 13-14, 2018. Batumi, Georgia : Publishing House Kalmosani, 2018. Pp. 266-269. 